\section{Comparative Evapotranspiration Rates of Tall Fescue Cultivars}

\author{
D.C. Bowman and L. Macaulay \\ Department of Plant Science, University of Nevada, Reno, NV 89557
}

Additional index words. Festuca arundinacea, ET, water use

Abstract. Comparative evapotranspiration (ET) rates of 20 cultivars of tall fescue (Festuca arundinacea Schreb.) were measured over 7 days in a greenhouse study. Small but significant differences in ET rates existed between the cultivars grown under nonlimiting water and nutrient conditions on day 1 following mowing. Greater differences had developed after 7 days of growth, with ET ranging from a low of $10.0 \mathrm{~mm} \cdot \mathrm{day}^{-1}$ for 'Shortstop' to a high of $13.5 \mathrm{~mm} \cdot$ day $^{-1}$ for 'Alta'. Day 7 ET was positively correlated $(r=0.82)$ with clipping dry weight. Six of the tall fescue cultivars were selected for a subsequent experiment to determine the stability of relative rankings for ET over time. Although average ET varied by up to a factor of two among five dates, the rankings were nearly identical for the five dates and were consistent with the rankings in the first experiment.

Mounting concern over the distribution of finite water supplies in the western United States underscores the importance of selecting turf species and cultivars with low water use rates. Numerous investigators have compared evapotranspiration (ET) rates between species (Aronson et al., 1987; Biran et al., 1981; Kim and Beard, 1988). Fewer published studies have examined intraspecific differences. Shearman (1986) reported relatively large differences in ET rates within 20 Kentucky bluegrass (Poa pratensis L.) and 12 perennial ryegrass (Lolium perenne L.) cultivars (1989).

Tall fescue is becoming an increasingly popular turfgrass due in part to desirable leaf texture, color, shoot density, and mowing qualities. In a recent field study, Kopec et al. (1988) investigated ET rates of six tall fescue cultivars using mini-lysimeters and found that the four turf-type cultivars used an average of $6 \%$ less water than the two forage types. The present greenhouse study was undertaken to evaluate water use rates of recently developed cultivars of turf-type tall fescues. A second objective was to determine the stability of cultivar rankings over time.

Experiments 1 and 2 were conducted in 1989 and 1990, respectively. In Expt. 1, 20 commercial tall fescue cultivars (Table 1) representing diverse genetic origins were grown in white cylindrical PVC containers, $15 \times 30 \mathrm{~cm}$ (diam/height), and with a bottom drainage hole. Containers were filled with $2.5 \mathrm{~kg}$ fritted clay (van Bavel et al., 1978) and spaced on $50-\mathrm{cm}$ centers. Seed of each cultivar was sown on 21 Nov. 1988, at 880 $\mathrm{mg} /$ container $\left(50 \mathrm{~g} \cdot \mathrm{m}^{-2}\right)$. After germination, the turf was established for 4 months in a greenhouse maintained at $23 / 18 \mathrm{C}$ day/night. During this period, the turf was irrigated with half-strength Hoagland's solution (Hoagland

Received for publication 17 May 1990. The cost of publishing this paper was defrayed in part by the payment of page charges. Under postal regulations, this paper therefore must be hereby marked advertisement solely to indicate this fact. and Arnon, 1950) to provide leaching. The turf was mowed about every 5 days to a height of $5 \mathrm{~cm}$, using a cylindrical jig as a guide.

Evapotranspiration was determined daily for 7 days (5-11 Apr. 1989) by the gravimetric mass balance method. A preliminary study indicated that slow, continuous capillary flow through the drain hole occurred when the containers were in contact with the wooden greenhouse benches. To prevent this, each container was placed on two wooden dowels to raise the bottom drainage hole 0.8 $\mathrm{cm}$ above the greenhouse bench, breaking capillary flow. Each container was irrigated at $0600 \mathrm{HR}$, allowed to drain to container capacity for $2 \mathrm{hr}$, and weighed. There was no need to plug the drain hole with this method, since drainage from the coarse fritted clay was rapid and had ceased com-

Table 1. Evapotranspiration rates and clipping dry weight (over 7 days) of 20 tall fescue cultivars (Expt. 1).

\begin{tabular}{|c|c|c|c|c|}
\hline \multirow[b]{2}{*}{ Cultivar (mm/period) } & \multicolumn{3}{|c|}{ Water use (mm/period) } & \multirow{2}{*}{$\begin{array}{c}\text { Clipping } \\
\text { dry wt } \\
\text { (g/container) }\end{array}$} \\
\hline & Day 1 & Day 7 & Days $1-7$ & \\
\hline Alta & $8.6 \mathrm{~b}$ & $13.1 \mathrm{a}$ & $70.1 \mathrm{a}$ & $3.04 \mathrm{a}$ \\
\hline Penngrazer & $9.0 \mathrm{ab}$ & $12.1 \mathrm{~b}$ & $67.9 \mathrm{ab}$ & $2.72 a b c$ \\
\hline Maverick & $9.8 \mathrm{a}$ & $11.3 \mathrm{c}$ & $67.0 a b c$ & 2.66 bcde \\
\hline Arid & $9.2 \mathrm{ab}$ & $11.3 \mathrm{c}$ & $66.0 \mathrm{bcd}$ & $2.77 \mathrm{ab}$ \\
\hline Cimarron & $9.2 \mathrm{ab}$ & $11.0 \mathrm{~cd}$ & $65.6 \mathrm{bcd}$ & $2.43 \mathrm{~b}-\mathrm{i}$ \\
\hline Rebel II & $8.9 a b$ & $11.1 \mathrm{~cd}$ & 64.4 bcde & $2.68 \mathrm{bcd}$ \\
\hline Olympic & $8.6 \mathrm{~b}$ & $10.8 \mathrm{cde}$ & $64.0 \mathrm{cde}$ & $2.30 \mathrm{e}-\mathrm{j}$ \\
\hline Finelawn I & $8.6 \mathrm{~b}$ & $11.1 \mathrm{~cd}$ & $63.8 \mathrm{cdef}$ & $2.51 \mathrm{~b}-\mathrm{h}$ \\
\hline Tribute & $8.9 \mathrm{ab}$ & 10.8 cde & 63.7 cdef & $2.60 \mathrm{~b}-\mathrm{f}$ \\
\hline Bonanza & $9.0 \mathrm{ab}$ & $10.6 \mathrm{cde}$ & $63.3 \mathrm{def}$ & $2.24 \mathrm{f}-\mathrm{k}$ \\
\hline Wrangler & $8.6 \mathrm{~b}$ & $11.0 \mathrm{~cd}$ & $63.3 \mathrm{def}$ & $2.52 \mathrm{~b}-\mathrm{h}$ \\
\hline Thoroughbred & $8.7 \mathrm{~b}$ & $10.7 \mathrm{cde}$ & $63.3 \mathrm{def}$ & $2.32 \mathrm{~d}-\mathrm{j}$ \\
\hline Apache & $9.0 \mathrm{ab}$ & 10.4 def & $63.2 \mathrm{def}$ & $2.20 \mathrm{~g}-\mathrm{k}$ \\
\hline Trailblazer & $8.6 \mathrm{~b}$ & $10.6 \mathrm{cde}$ & $62.8 \mathrm{def}$ & $2.35 \mathrm{~d}-\mathrm{j}$ \\
\hline Mustang & $8.6 \mathrm{~b}$ & $10.4 \mathrm{def}$ & $62.6 \mathrm{def}$ & 2.17 hijk \\
\hline Monarch & $8.9 \mathrm{ab}$ & 10.4 def & $62.4 \mathrm{def}$ & $2.14 \mathrm{ijk}$ \\
\hline Mesa & $8.5 \mathrm{~b}$ & $10.5 \mathrm{de}$ & $62.3 \mathrm{def}$ & $2.39 c-i$ \\
\hline Murietta & $9.3 \mathrm{ab}$ & $9.8 \mathrm{fg}$ & 61.6 ef & $1.93 \mathrm{k}$ \\
\hline Silverado & $8.6 \mathrm{~b}$ & $10.1 \mathrm{efg}$ & $61.5 \mathrm{ef}$ & $2.20 \mathrm{~g}-\mathrm{k}$ \\
\hline Shortstop & $8.9 \mathrm{ab}$ & $9.6 \mathrm{~g}$ & $60.2 \mathrm{f}$ & $2.01 \mathrm{jk}$ \\
\hline Average & 8.9 & $10.8^{\circ}$ & 63.9 & 2.42 \\
\hline Pan evaporation $y$ & $92 \pm 2$ & $76 \pm 6$ & $557 \pm 32$ & \\
\hline
\end{tabular}

${ }^{2}$ Values are means of four replicates. Mean separation in columns by Duncan's multiple range test, $P=0.05$.

${ }^{\mathrm{y}}$ Greenhouse pan evaporation is expressed as $\mathrm{ml} /$ container. pletely by $2 \mathrm{hr}$. The containers were reweighed the following day at $0600 \mathrm{HR}$ and daily ET determined as the difference. However, daily ET is actually water loss that occurred over $22 \mathrm{hr}$. Immediately following the second weighing, each container was irrigated with $250 \mathrm{ml}$ of nutrient solution and allowed to drain for $2 \mathrm{hr}$ to bring each container back to a standard container capacity. Each was then reweighed to establish the initial weight for the next daily cycle. This entire sequence was repeated daily during the 7-day experiment.

In Expt. 1, the turf was mowed at $5 \mathrm{~cm}$ immediately before the first weighing and then again after the final weighing on day 7 . Clipping fresh and dry weights were measured for the second mowing.

A second experiment was conducted in April-May 1990 to examine the stability of cultivar rankings as determined using the greenhouse mini-lysimeter method described above. Seed of each of six tall fescue cultivars (Table 2) was sown at $880 \mathrm{mg} /$ container on 26 Nov. 1989, with subsequent turf culture as described above for Expt. 1. The turf was mowed every 7 days during the experiment. Evapotranspiration was determined on the 7th day of each of five weekly mowing cycles from 7 Apr. to 13 May 1990. Each measurement was thus on turf with 7 days of growth.

A completely randomized block design with four replicates was used in both experiments. Data were analyzed by analysis of variance and, when significantly different, means were separated by Duncan's multiple range test.

Evaporative conditions in the greenhouse were estimated from the daily weight loss of four open pans of water, $15 \times 12 \mathrm{~cm}$ (diam/depth), positioned within each block at the same height as the turf canopy. The 
Table 2. Evapotranspiration rates for six tall fescue cultivars assessed on five dates in 1990 (Expt. 2).

\begin{tabular}{llllllc}
\hline \hline & \multicolumn{5}{c}{ Evapotranspiration rate $\left(\mathrm{mm} \cdot\right.$ day- $^{-1}$ ) } & Total \\
\cline { 2 - 7 } Cultivar & $8 \mathrm{Apr}$. & $22 \mathrm{Apr}$. & $29 \mathrm{Apr}$. & $6 \mathrm{May}$ & $13 \mathrm{May}$ & $(\mathrm{mm} / 5 \mathrm{days})$ \\
\hline Alta & $6.0 \mathrm{a}^{\mathrm{z}}$ & $8.9 \mathrm{a}$ & $10.0 \mathrm{a}$ & $11.3 \mathrm{a}$ & $12.8 \mathrm{a}$ & $49.1 \mathrm{a}$ \\
Finelawn I & $5.4 \mathrm{ab}$ & $8.0 \mathrm{bc}$ & $9.2 \mathrm{~b}$ & $10.3 \mathrm{~b}$ & $11.4 \mathrm{~b}$ & $44.3 \mathrm{~b}$ \\
Maverick & $5.2 \mathrm{~b}$ & $8.1 \mathrm{~b}$ & $8.9 \mathrm{bc}$ & $10.2 \mathrm{~b}$ & $11.4 \mathrm{~b}$ & $44.0 \mathrm{~b}$ \\
Tribute & $5.0 \mathrm{bc}$ & $7.3 \mathrm{bcd}$ & $8.5 \mathrm{c}$ & $9.6 \mathrm{c}$ & $10.9 \mathrm{c}$ & $41.4 \mathrm{c}$ \\
Silverado & $5.1 \mathrm{bc}$ & $7.2 \mathrm{~cd}$ & $7.8 \mathrm{~d}$ & $8.6 \mathrm{~d}$ & $9.7 \mathrm{~d}$ & $38.5 \mathrm{~d}$ \\
Shortstop & $4.5 \mathrm{c}$ & $6.6 \mathrm{~d}$ & $7.2 \mathrm{e}$ & $8.2 \mathrm{~d}$ & $8.9 \mathrm{e}$ & $35.4 \mathrm{e}$ \\
Average & 5.2 & 7.7 & 8.6 & 9.7 & 10.8 & 42.1 \\
Pan evaporation & $41 \pm 3$ & $50 \pm 2$ & $62 \pm 5$ & $64 \pm 5$ & $68 \pm 4$ & \\
\hline
\end{tabular}

${ }^{2}$ Values are means of four replicates. Mean separation in columns by Duncan's multiple range test, $P=0.05$

${ }^{y}$ Greenhouse pan evaporation is expressed as $\mathrm{ml} /$ container.

water level in each pan was $1 \mathrm{~cm}$ from the rim. The values for evaporation permit comparisons of evaporative conditions between days and experiments only, and do not represent potential ET in the greenhouse.

In both experiments, ET was measured under nonlimiting nutrient and moisture conditions. Each container held $\approx 1900 \mathrm{ml}$ of available water, with loss being replenished daily. The amount of water used on any given day was $\approx 10 \%$ of the total available water. Extensive root development, as evidenced by root growth at the bottom drainage hole, was noted for all cultivars.

In Expt. 1, there were small but significant differences in ET between cultivars immediately following mowing (Table 1 , day 1). 'Maverick' had the highest ET rate (9.8 mm.day $\left.{ }^{-1}\right)$, whereas 'Mesa' had the lowest $\left(8.5 \mathrm{~mm} \cdot\right.$ day $\left.^{-1}\right)$. Larger and consistent differences among cultivars developed over the next 6 days (for brevity, only data for days 1 and 7 and cumulative ET are presented, Table 1). The forage-types, 'Alta' and 'Penngrazer', had the highest ET rates on day 7, while the turf-types, 'Murietta', 'Shortstop', and 'Silverado', had the lowest ET rates, averaging $\approx 22 \%$ less than the forage-types. Average ET across all cultivars was $22 \%$ greater on day 7 than on day 1 , despite a lower evaporative demand in the greenhouse on day 7 (76 vs. $92 \mathrm{ml} \mathrm{H} \mathrm{O}$ lost from the pans, respectively). This difference most likely was due to the growth of new clippings over the 7 days, increasing the evaporative surface area. The ranking of cultivars was very similar for day 7 ET and for cumulative ET for days 1 though 7 (Spearman's correlation coefficient $=0.958, P<$ $0.001)$.

There were large differences in clipping dry weight (and fresh weight, data not shown) after 7 days of growth (Table 1). 'Alta', 'Arid', and 'Penngrazer' had the highest clipping dry weights (average of $2.84 \mathrm{~g} / \mathrm{con}$ - tainer per 7 days), whereas 'Monarch', 'Marietta', and 'Shortstop' had the lowest (average of $2.03 \mathrm{~g} /$ container per 7 days). Evapotranspiration on day 7 was strongly correlated with clipping dry weight $(r=0.82, P<$ $0.001)$. Visual inspection of the canopies suggested that greater growth was primarily the result of increased vertical elongation rate of the leaves rather than higher shoot density in the faster-growing cultivars.

In the study of the stability of rankings over time (Expt. 2), there were significant effects of both cultivar and date on ET, but there was no significant cultivar $\times$ time interaction. The ranked order of the cultivars was nearly identical on all five dates (Table2) despite an approximately 2-fold difference in average ET between dates. 'Alta' again had the greatest water use and 'Shortstop' the least, averaging $72 \% \pm 2 \%$ of that by 'Alta'. In Expt. 1, evapotranspiration by 'Shortstop' on day 7 was $73 \%$ of that by 'Alta'. The overall ranking of the six culivars was consistent with their ranking in Expt. 1, except that 'Finelawn I' and 'Maverick', which had very similar ET rates, were reversed.

These data indicate that significant intraspecific differences in ET exist in tall fescue, similar to the conclusions for Kentucky bluegrass (Shearman, 1986) and perennial ryegrass (Shearman, 1989). In these latter two species, ET was positively correlated with vertical elongation rate and negatively correlated with verdure. Although vertical elongation rate and verdure were not measured in the present study, clipping dry weight was strongly correlated with ET. Because the cultivars in this study were grown in spaced containers (which may maximize edge and advective effects), differences in ET could be related to the amount of horizontal leaf growth past the edge of the container. However, differences in ET were also found for uniformly mowed canopies (Expt. 1, day 1) that were not due to horizontal leaf growth.

These data are also consistent with the observation of Kopec et al. (1988) that foragetype tall fescues use more water than turftypes under field conditions. However, the differences in ET between forage-types and turf-types reported by Kopec et al. (1988) were relatively small compared to this study, possibly due to the dissimilarity of environments and fertilization practices. The results of Expt. 1 in the present study indicate that intraspecific differences in both ET and growth rate are highly expressed in well-fertilized, rapidly growing turf, although the large differences in ET may. have been the result of using lysimeters spaced on the greenhouse bench. Evapotranspiration rates were relatively high in both experiments. For example, ET in Expt. 1 over the 7 days averaged $9.3 \mathrm{~mm} \cdot$ day $^{-1}$ for the 20 cultivars used in this greenhouse study. This is $37 \%$ greater than the average of $6.8 \mathrm{~mm}$ under field conditions reported by Kopec et al. (1988). Again, this difference is probably due to edge and advective effects. Ranking of cultivars, as established in the greenhouse using mini-lysimeters (Expt. 2), is very stable over time and relatively independent of variable evaporative conditions. That there was no cultivar $\times$ time interaction suggests that this simple method may be useful in screening for water use rates. However, to validate these findings, future comparisons between tall fescue cultivars identified as being high and low water users in this study should be made under field conditions.

\section{Literature Cited}

Aronson, L.J., A.J. Gold, and R.J. Hull. 1987. Cool-season turfgrass responses to drought stress. Crop Sci. 27:1261-1266.

Biran, I., B. Bravdo, I. Bushkin-Harav, and E. Rawitz. 1981. Water consumption and growth rate of 11 turfgrasses as affected by mowing height, irrigation frequency, and soil moisture. Agron. J. 75:85-90.

Hoagland, D.R. and D.I. Amen. 1950. The water culture method for growing plants without soil Calif. Agr. Expt. Sta. Circ. 347.

Kim, K.S. and J.B. Beard. 1988. Comparative turfgrass evapotranspiration rates and associated morphological characteristics. Crop Sci. 28:328-332

Kopec, D.M., R.C. Shearman, and T.P. Riordan. 1988. Evapotranspiration of tall fescue turf. HortScience 23:300-301

Shearman, R.C. 1986. Kentucky bluegrass cultivar evapotranspiration rates. HortScience 21:455-457

Shearman, R.C. 1989. Perennial ryegrass cultivar evapotranspiration rates. HortScience 24:767769.

van Bavel, C.H.M., R. Lascano, and D,R. Wilson. 1978. Water relations of fritted clay. Soil Sci. Soc. Amer. J. 42:657-659. 